\title{
A Case of Identity: HOX Genes in Normal and Cancer Stem Cells
}

\author{
Jessica Smith ${ }^{1,2,+}$, Ahmad Zyoud ${ }^{1,2,+}$ (i) and Cinzia Allegrucci ${ }^{1,2, *(1)}$ \\ 1 SVMS, Faculty of Medicine and Health Sciences, University of Nottingham, Sutton Bonington Campus, \\ Loughborough LE12 5RD, UK; stxjt15@exmail.nottingham.ac.uk (J.S.); \\ svxaz@exmail.nottingham.ac.uk (A.Z.) \\ 2 Nottingham Breast Cancer Research Centre and Centre for Cancer Sciences, University of Nottingham, \\ Centre for Biomolecular Sciences, Nottingham NG7 2RD, UK \\ * Correspondence: cinzia.allegrucci@nottingham.ac.uk; Tel.: +44-(0)-115-951-6487 \\ + These authors contributed equally to the paper.
}

Received: 21 March 2019; Accepted: 9 April 2019; Published: 10 April 2019

\begin{abstract}
Stem cells are undifferentiated cells that have the unique ability to self-renew and differentiate into many different cell types. Their function is controlled by core gene networks whose misregulation can result in aberrant stem cell function and defects of regeneration or neoplasia. HOX genes are master regulators of cell identity and cell fate during embryonic development. They play a crucial role in embryonic stem cell differentiation into specific lineages and their expression is maintained in adult stem cells along differentiation hierarchies. Aberrant HOX gene expression is found in several cancers where they can function as either oncogenes by sustaining cell proliferation or tumor-suppressor genes by controlling cell differentiation. Emerging evidence shows that abnormal expression of HOX genes is involved in the transformation of adult stem cells into cancer stem cells. Cancer stem cells have been identified in most malignancies and proved to be responsible for cancer initiation, recurrence, and metastasis. In this review, we consider the role of HOX genes in normal and cancer stem cells and discuss how the modulation of HOX gene function could lead to the development of novel therapeutic strategies that target cancer stem cells to halt tumor initiation, progression, and resistance to treatment.
\end{abstract}

Keywords: HOX genes; stem cells; cancer stem cells; self-renewal; differentiation; targeted therapy

\section{HOX Genes Are Master Regulators of Embryonic Development}

HOX genes encode evolutionarily conserved transcription factors that are expressed under temporal and spatial control to establish patterning and morphogenesis in the vertebrate embryo. They play a critical role during development, and either loss or gain of function of HOX genes can lead to homeotic transformation and abnormal formation of body structures [1]. In humans and mice, HOX genes are organized in four paralogous gene clusters (A, B, C, D) coding for 39 genes. Their expression is tightly controlled by their clustered organization so that their activation in the posterior part of the primitive streak occurs by a process of temporal and spatial collinearity depending on their location within the cluster. The position of HOX genes within the cluster corresponds to their positional expression along the anterior-posterior axis, with expression following the direction from the $3^{\prime}$ side (anterior) to the $5^{\prime}$ (posterior). Their temporal expression is also coordinated so that HOX genes positioned $3^{\prime}$ in the cluster are expressed earlier than those at the $5^{\prime}$ [2]. In addition, a phenomenon of posterior dominance can be observed whereby posterior genes are dominant with respect to more anterior genes when expressed in adjacent areas [3]. This coordinated expression is regulated by key developmental signals within the embryo, including Wnt ligands, retinoic acid (RA), and fibroblast 
growth factor (FGF) [4,5]. Important upstream regulators of HOX gene transcription are CDX genes. These are direct targets of Wnt, RA, and FGF and therefore integrate signaling pathway networks to regulate HOX gene expression [4].

Different structural and epigenetic parameters have been described contributing to the collinearity of HOX gene expression. These include their chromosomal cluster organization, cis-regulatory elements (enhancers and lncRNA), histone modifications, chromosome boundaries, and 3D chromatin conformation [6]. During development, the regulation of HOX genes is achieved by methylation of Histone H3 residues by Trithorax (TrxG) and Polycomb (PcG) group proteins, which establish the active H3K4me3 and repressive H3K27me3 marks, respectively. These epigenetic modifiers create bivalent domains and a poised state in the pre-gastrulating embryo by transcriptional control of developmental genes. In the bivalent state, H3K27me3 is dominant over the H3K4me3 mark, with genes controlled by these marks being repressed as default [7]. The removal of H3K27me3 by histone demethylases then allows the prompt expression of patterning and lineage specifier HOX genes following a temporal and special collinearity $[8,9]$. At gastrulation, trimethylation of $\mathrm{H} 3 \mathrm{~K} 27$ mediated by the Polycomb Repressive Complex 2 (PRC2) and recruitment of the Polycomb Repressive Complex 1 (PRC1) induce chromatin condensation to maintain a permanent silencing of the HOX genes in a lineage-specific manner $[9,10]$. The silencing of non-lineage tissue specific genes can then be further reinforced by DNA methylation, a stable and heritable epigenetic mark [11,12]. Therefore, during cell fate determination the chromosomal domains marked by active H3K4 or silent H3K27 methylation are mutually exclusive and are programmed to establish the HOX code and epigenetic memory of differentiated cells [13]. Together with the epigenetic regulation mediated by PcG and TrxG proteins, intergenic transcription of miRNA and long non-coding RNAs (lncRNA) regulate the expression of HOX genes. HOTAIR, HOTAIRM1, and HOTTIP are IncRNA located in the cluster, and they have been shown to configure the epigenetic profile of the HOX loci by association with PcG and TrXG proteins and to control gene expression either in cis or in trans [14]. For instance, the lncRNA HOTAIR is located in the HOXC cluster and required for the silencing of HOXD genes through interaction with the PRC2 complex and for the establishment of the repressive H3K27me3 mark [14]. On the other hand, HOTAIRM1 is a IncRNA located within the HOXA cluster that plays a role in regulating the expression of $3^{\prime}$ HOXA genes by preventing the accessibility of the lysine-specific demethylase 6A (UTX) and by delaying the expression of central genes in the cluster. The 5' HOXA genes are instead regulated by the IncRNA HOTTIP, which is located upstream of HOXA13 [15]. As a result of their epigenetic regulation, $H O X$-coded transcription factors can act as either transcriptional activators or repressors of target genes. These consist of factors that regulate diverse biological processes and include a network of transcription factors, signaling molecules, components of signaling pathways, and "realizator" genes that are directly involved in cell differentiation and tissue organization $[16,17]$. The diversity and specificity of HOX proteins is realized by their interaction with cofactors that belong to the TALE family. These include the PBC and MEINOX classes of transcription factors, with the PBC family comprising PBX proteins (PBX1-4) and the MEINOX family including MEIS (MEIS1-3) and PREP (PRE1-2) proteins. All of these transcription factors cooperate with HOX proteins by forming heteromeric complexes, $[18,19]$ and their diverse and context-dependent interaction regulates cell fate decisions and specific cell functions during embryo patterning and morphogenesis.

\section{HOX Genes and Cellular Identity}

The concerted actions of HOX proteins and their cofactors are responsible not only for HOX gene homeotic function, but also for regulation of organogenesis. In this process, the function of HOX genes is to control cell proliferation, differentiation, migration, and apoptosis [16]. The resulting embryonic HOX gene expression profiles in each body region are then sustained in the adult so that cell and tissue characteristics are maintained according to a specific "HOX code" [20].

At the cellular level, the primary role of HOX genes is to regulate cell specification and tissue differentiation. During embryogenesis, the expression of HOX genes maintains positional information, 
and it is epigenetically inherited so that cells can maintain a memory of their identity during the lifetime of an organism. A significant demonstration of the role played by HOX genes in the regulation of cell identity is provided by their expression pattern in adult human fibroblasts. In these cells, $H O X$ gene expression can predict their original embryonic position along the developmental axes [21,22]. For instance, the expression of HOXA and HOXD genes reflects the location along the proximal and distal axis of the limbs, whereas HOXC genes correlate with the anterior and posterior axis of the trunk. HOXB genes are instead associated with fibroblasts of non-dermal origin [22]. The same feature of positional identity is applicable to HOX gene expression profiles in smooth and skeletal muscle cells [23,24].

The expression of HOX proteins in different tissues, or in the same tissue at different anatomical locations, maintains correct cell identities during differentiation. Indeed, it has been demonstrated that HOX genes play a crucial role in stem cells both in embryonic and in adult tissues by controlling lineage specification, differentiation, and tissue maturation [25].

\section{HOX Genes in Embryonic Stem Cells}

HOX genes are not expressed before gastrulation, and they are not transcribed in embryonic stem cells (ESC) derived from the inner cell mass of a blastocyst [26]. ESC are pluripotent cells that can differentiate into all of the different cell types that comprise the body. HOX genes in ESC are regulated by bivalent chromatin domains so that they are poised for activation after differentiation. As a result, the coverage of the polycomb complex PRC2 in ESC is not as extensive as in differentiated cells with silenced HOX gene expression [27]. ESC present an active epigenetic repression of HOX genes in their undifferentiated state, with HOX gene activation being induced upon differentiation [28]. At this stage, histone demethylases remove the repressive H3K27me3 mark from HOX lineage specifier genes, whilst PcG proteins maintain cell identity through transcriptional repression of $H O X$ genes that are specific to other lineages $[29,30]$. In the mouse, Wnt3 induces the gradual and collinear activation of the HOX gene cluster during gastrulation [31]. This mechanism is recapitulated in differentiating mouse epiblast stem cells with concomitant activation of $C d x 2$ [32] and in human induced pluripotent stem cells with induction of a posterior mesoderm phenotype [33].

RA is another key inducer of HOX gene expression during ESC differentiation. RA treatment of ESC can significantly increase the induction of neural differentiation and upregulate the expression of HOX genes [34]. RA responsive elements (RARE) are found in the regulatory regions of many HOX genes which respond to RA signaling in a collinear fashion, with genes at $3^{\prime}$ responding to the signal more rapidly than those at the $5^{\prime}$ of the cluster [35,36]. RA receptor $\gamma$ is essential for RA-induced activation of HOX gene transcription. Indeed, knockdown of RA receptor $\gamma$ in mouse ESC impairs differentiation and reduces the expression of Hoxa and Hoxb cluster genes as well as the expression of their cofactors $P b x 1$ and Meis1 [37]. Importantly, RA/RA receptor $\gamma$ signaling is required to remove PcG repressive marks from most bivalent HOX gene regulatory regions during ESC differentiation via recruitment of the H3K27me3 demethylase UTX-KDM6A [34,38,39]. Specific HOX genes are involved in the control of cell fate specification and differentiation of ESC into different lineages. For instance, inducible expression of Hoxb1 in mouse ESC can induce the differentiation and expansion of posterior neural stem/progenitor cells [40]. On the other hand, HOXB4 acts as a master regulator of hematopoietic differentiation in both mouse and human pluripotent stem cells [41-43]. Hoxb4 can in fact regulate multiple transcription factors involved in hematopoiesis and chromatin modifiers, thus playing a role in establishing the epigenetic landscape of the developing hematopoietic stem/progenitor cells [41]. Finally, Hox6 gene paralogues (Hoxa6, Hoxb6, Hoxc6) control the differentiation of mouse ESC into insulin producing pancreatic cells [44]. Therefore, the role of HOX genes during embryonic development is mirrored in ESC and their expression allows the control of ESC differentiation to the three germ layers. 


\section{HOX Genes in Adult Stem Cells}

The positional identity provided by HOX gene expression during development and differentiation into adult tissues provides a mechanism for imposing cell identity and fate restriction. This information is maintained in adult stem cells (ASC) and along their differentiation hierarchies. This mechanism can be clearly observed in mesenchymal stem cells (MSC). These cells, isolated from different tissues including the bone marrow and adipose tissue, can differentiate to fat, bone, and cartilage. Despite their phenotypic similarity, MSC derived from different tissues present a profile of HOX gene expression that mirrors that of their developmental origin. The topographical specificity of HOX genes in MSC is also maintained after differentiation, indicating that HOX genes play a role in the specification of MSC identity $[45,46]$. Indeed, umbilical cord MSC (UC-MSC) and bone marrow MSC (BM-MSC) show a different profile of HOX gene expression. HOXA9, HOXB7, HOXC10 and HOXD6 are expressed in UC-MSC, whereas BM-MSC express HOXB7 and HOXD6 [47].

Patterns of HOX gene expression can also distinguish stem cell populations of functionally distinct tissues and influence their differentiation potential. For instance, the HOX code of skeletal stem/progenitor cells (SSC) can affect their differentiation into resident tissue osteoblasts. These stem cells show a HOX gene expression profile based on their embryonic origin. Therefore, mouse SSC in the tibia maintain their embryonic identity being of mesodermal origin and expressing Hoxa1. On the other hand, those in the mandibular originate from the neural crest and do not express HOX genes. This positional memory has been shown to affect the differentiation and regeneration potential of SSC when ectopically transplanted as the original HOX code is retained upon transplantation [48]. A similar behavior can be observed in two populations of cord blood stem cells, the UC-MSC and the unrestricted somatic stem cells (USSC). In contrast to UC-MSC, USSC do not express HOX genes, and therefore they retain the potential to differentiate into three germ layers similarly to ESC [47].

$H O X$ genes also play a critical role in lineage restriction, as shown during the differentiation of the hematopoietic system. In this lineage, HOXA9, HOXB3, and HOXB4 are expressed in hematopoietic stem cells (HSC) which can differentiate into myeloid cells predominantly expressing HOXA genes, and erythroid and lymphoid cells expressing HOXB and HOXC genes, respectively [49,50]. HOX genes are also involved in the differentiation of other lineages. For example, HOXA10 mediates osteogenic differentiation [51], whereas Hoxa3 and Hoxd3 induce differentiation of endothelial cells and angiogenesis in the mouse [52]. In the nervous system, $3^{\prime}$ HOX genes play a dominant role in neurogenesis and HOXB4 can drive neural differentiation in the neural tube, whereas Hoxb1 is essential for driving mouse neural stem cells to hindbrain [53]. Finally, several studies demonstrated a role for HOX genes in the regulation of terminal differentiation and tissue maturation. For instance, HOXA5 and HOXD10 are required for maintaining differentiated endothelial cells in a mature and quiescence state [28]. Similarly, Hoxa2 and Hoxb1 regulate the maturation of facial nerves in the mouse [54]. Although these studies suggest a positive effect of HOX gene expression during terminal differentiation, final tissue maturation can also require downregulation of $H O X$ gene expression. This is the case for mature bone marrow cells that require downregulation of HOX genes specifying the hematopoietic lineage in order to terminally differentiate [49]. Altogether, these studies show the importance of the HOX code in maintaining ASC function and restriction of differentiation programs.

\section{HOX Genes in Cancer Stem Cells}

The fidelity of HOX gene expression in stem cells and their differentiated progenies is critical for normal tissue homeostasis. Consequently, alteration of HOX gene expression can play a critical role in the development of cancer [55]. HOX genes are frequently deregulated in cancer and many studies have shown they can function as tumor modulators by playing either an oncogenic or a tumor suppressive role [56]. Indeed, upregulation of HOX genes that are normally expressed in undifferentiated cells drives oncogenesis, whereas downregulation of HOX genes that are normally expressed in differentiated tissues results in the abolition of their function as tumor suppressors [57]. An altered expression of defined HOX clusters is found in different cancers, including alteration of 
HOXA genes in breast and cervical cancers, HOXB in colon cancer, HOXC in prostate and lung cancers, and HOXD in colon and breast cancer [58,59]. The involvement of HOX genes in cancer is therefore complex, with mechanisms of deregulation of specific HOX genes differing among cancer types [55].

The role of HOX genes in maintaining cell identity limits the ability of cells to transition between different phenotypes. However, research on HOX genes during regeneration and wound healing in lower organisms have highlighted a role for these transcription factors in dedifferentiation and in shifting cells between metastable states. Therefore, aberrant HOX gene expression can lead to loss of differentiation and increased cell plasticity in the context of regeneration [60].

In cancer, this type of phenotypic plasticity can drive cells to re-acquire self-renewal and a stem cell phenotype, thus leading to the formation of cancer stem cells (CSC) and tumor initiation [12]. CSC are malignant stem/progenitor cells that have been identified in many different tumor types $[61,62]$. They can originate from transformation of normal tissue-resident stem/progenitor cells or reprogramming of differentiated cells $[63,64]$. Irrespective of their origin, CSC retain a high degree of plasticity and the ability to both proliferate and give rise to the heterogeneous bulk of the tumor in response to signals from the tumor microenvironment. CSC are involved in tumor initiation, progression, invasion, resistance to treatment and are directly linked to poor clinical outcome [65-67]. The formation of CSC involves the acquisition of a similar epigenetic landscapes to that of normal stem cells [12], with bivalent chromatin marks and DNA methylation dynamically regulating differentiation and stemness genes [68].

Aberrant epigenetic regulation of HOX gene expression is common in cancer and can contribute to CSC plasticity [69]. By screening homeobox gene expression in breast CSC, we demonstrated that epigenetic silencing of HOXC8 mediated by MIR-196 and DNA methylation induces a CSC phenotype in normal mammary stem cells, and it results in their increased self-renewal, impaired differentiation, and augmented tumorigenic potential [70]. A similar phenomenon was observed in other types of CSC. Epigenetic alteration of HOXD9 and HOXA10 in glioma CSC induces cell proliferation and survival [71,72]. Similarly, hypomethylation of the RA-cis regulatory element in leukemic stem cells induces expression of $H O X B$ cluster genes driving the expansion of the malignant HSC pool [73]. Epigenetic regulation through expression of $H O X$-derived lncRNA can also influence the function of CSC [74]. HOTAIR expression can regulate the process of epithelial-to-mesenchymal transition (EMT) and acquisition of a CSC phenotype. HOTAIR sustains EMT induced by TGF $\beta$ in colon CSC [75], and it suppresses the tumor suppressor activity of MIR-7 via regulation of HOXD10 whilst sustaining the expression of genes inducing EMT in breast CSC [76]. HOTAIR plays an important role in the transformation of CSC also in lung, liver, and brain cancers [77-79]. HOTTIP, another lncRNA derived from the HOX cluster, has also been shown to be involved in CSC function. In pancreatic cancer, HOTTIP enhances CSC properties by induction of HOXA9 and activation of the Wnt pathway [80].

Further studies have shown the role of HOX genes in CSC transformation. For instance, HOXA4 and HOXA9 are enriched during the transformation of colon CSC, and their expression contributes to sustained CSC self-renewal [81]. Upregulation of HOXA9 has also been shown to sustain the self-renewal of HSC in acute myeloid leukemia (AML) and the NUP98-HOXA9 fusion protein induces long-term proliferation and impaired differentiation of leukemic CSC [82,83]. In the breast, HOXB3 has been shown to sustain the proliferation and drug resistance of breast CSC [84]. Finally, downregulation of HOXA5 and RA signaling in mammary cells leads to loss of the epithelial phenotype and acquisition of CSC characteristics [85]. HOXA5 plays a similar role in colon cancer, as silencing of HOXA5 by Wnt signaling maintains the pool of CSC and reactivation of HOXA5 by RA treatment induces loss of the CSC (Table 1) [86].

Overall, the mentioned studies show a clear role of HOX genes in CSC function; however, the functional gene networks downstream of $\mathrm{HOX}$ activation still needs to be fully determined. 
Table 1. HOX genes and HOX-cluster derived lncRNA in CSC.

\begin{tabular}{ccl}
\hline HOX Genes and lncRNA & CSC Type & \multicolumn{1}{c}{ Function } \\
\hline \multirow{2}{*}{ HOXA5 } & Breast & Silencing of HOXA5 induces loss of differentiation [85] \\
\cline { 2 - 3 } & Colon & Silencing of HOXA5 maintains the pool of CSC [86] \\
\hline HOXA4 & Colon & Expression of HOXA4 induces CSC self-renewal [87] \\
\cline { 2 - 3 } & AML & $\begin{array}{l}\text { HOXA9 and NUP98-HOXA9 fusion protein sustain self-renewal and impair } \\
\text { differentiation of CSC [82,83] }\end{array}$ \\
\hline HOXA9 & Glioblastoma & Expression of HOXA9 induces CSC self-renewal [87] \\
\hline HOXB cluster & Leukemia & Expression of HOXB genes induces expansion of CSC [73] \\
\hline HOXB3 & Breast & Expression of HOXB3 sustains proliferation of drug resistance of CSC [84] \\
\hline HOXC8 & Breast & Silencing of HOXC8 sustains self-renewal and impairs differentiation of CSC [70] \\
\hline HOXD9 & Glioma & Silencing of HOXD9 induces self-renewal and survival of CSC [71] \\
\hline HOTAIR & Colon & Expression of HOTAIR induces EMT and stemness [75] \\
\hline & Breast & Expression of HOTAIR induces EMT and stemness through activation of HOXD10 [76] \\
\hline & Lung & Expression of HOTAIR induces EMT and stemness [78] \\
\hline & Liver & Expression of HOTAIR induces EMT and stemness [77] \\
\hline HOTTIP & Glioma & Expression of HOTAIR induces proliferation and invasion of CSC [79] \\
\hline & Pancreas & Expression of HOTTIP induces CSC proliferation by induction of HOXA9 [80] \\
\hline
\end{tabular}

The deregulation of HOX genes has an impact on key processes that sustain CSC function, including self-renewal, cell death evasion, and the ability to metastasize. HOX genes can sustain cell proliferation via autocrine stimulation by growth factors and stimulation of cell cycle progression and resistance to cell death [88]. For example, HOXB7 activates the FGF-MAPK (fibroblast growth factor- mitogen-activated protein kinases) and PI3K/Akt (phosphoinositide 3-kinase/protein kinase B) signaling pathways in breast and gastric cancer, respectively $[89,90]$. Other HOX genes have a direct effect on cell cycle progression by inducing expression of Cyclin D1, like HOXB7 in colorectal cancer [91] and HOXA9 in leukemia [92]. HOX genes are also involved in the acquired resistance to cell death. Indeed, HOXB7 can induce resistance to cytotoxic drugs [93,94], and loss of HOXA5 results in resistance to apoptosis induced by TP53 in breast cancer [95].

Another important CSC characteristic regulated by HOX genes is invasion and metastasis. Several HOX genes are involved in the regulation of EMT, a process involved in metastatic spread and acquisition of CSC characteristics. This role has been demonstrated for HOXB7 which promotes EMT in breast cancer [89], and for HOXA10 whose silencing induces EMT in endometrial and lung cancer $[96,97]$.

\section{HOX Genes and CSC Targeted Therapies}

Therapeutic targeting of CSC is a growing area of research, with drug discovery programs aimed at finding specific therapies that can eradicate this tumor initiating and disseminating cell population. Current evidence supports an important role played by HOX genes in the regulation of both normal and CSC function. Therefore, HOX genes may represent novel cancer biomarkers for targeted therapy and prediction of drug response and prognosis. Although targeting HOX genes represents an exciting opportunity, many challenges remain. First, transcription factors are not easily "druggable". Targeting these proteins is difficult, mainly due to their intracellular or nuclear localization and their interaction with different cofactors [98]. This limitation could be overcome by developing targeted gene editing approaches coupled with novel drug delivery systems, and this certainly represents a new avenue with a great potential.

Another possibility would be to interfere with targets downstream of the HOX genes. This approach is also particularly important when considering the functional versatility of $H O X$ genes. As previously discussed, the same HOX gene can play different roles by functioning either as an oncogene or a tumor suppressor in different cancer types. In addition, some HOX genes with conserved patterning function 
present a high degree of redundancy, and therefore the inhibition of one gene can be overcome by expression of a paralogous gene or another gene in the same cluster $[99,100]$. Targeting the interaction of HOX proteins with their cofactors PBS or MEIS could have the potential to inhibit the oncogenic potential of HOX genes in a specific cellular context. The inhibition of HOX-PBX complexes has already been achieved by using the antagonist peptide HXR9 which can induce apoptosis in a number of cancers, including solid tumors of the breast, prostate, ovarian, kidney, skin, lung, and blood tumors such as myeloma and AML [101].

Although these approaches seem promising, therapeutic targeting of CSC remains a clinical challenge, mainly due to their inherent plasticity that is influenced by the tumor microenvironment. Therefore, strategies aimed at targeting the microenvironment as well as CSC could prove effective. For example, HOXA5 and HOXD10 are expressed in normal epithelial and endothelial cells in the breast and their silencing is associated with CSC expansion and cell migration. Restoring the expression of both HOX genes could therefore be more effective and limit plasticity by targeting both CSC and angiogenesis [102-104].

Epigenetic therapies could also be instrumental for targeting HOX gene expression in CSC and affect their function by reducing self-renewal and promoting differentiation [105]. This approach is viable as several histone demethylase and histone deacetylase inhibitors are already clinically approved and many are currently being tested in clinical trials. Differentiation therapy approaches are also effective in targeting CSC by re-establishing normal HOX gene expression. RA can induce terminal differentiation of CSC, and it is currently used as standard of care for the treatment of acute promyelocytic leukemia [106]. We have also shown that RA is effective in re-establishing HOXC8 expression in breast CSC [70], and other studies demonstrated the same effect in restoring expression in HOXA5 in colon and breast CSC $[85,86]$.

HOX gene expression could also inform cancer prognosis given that cancers that are enriched with CSC are also associated with a worse patient outcome. An association between HOX expression and poor prognosis has already been established for breast cancer and lung adenocarcinoma (HOXB7), renal clear cell carcinoma (HOXC11), mesothelioma (HOXB4), oral squamous cell carcinoma (HOXD13), gastric cancer (HOXC6), thyroid cancer (HOXC10), bladder cancer (HOXB13), and AML (HOXA9) [101]. In addition, HOX gene expression profiling in circulating CSC could provide a powerful prognostic tool for the development of personalized therapies [107]. We have shown that HOX gene profiles in CSC defines breast cancer molecular subtypes, suggesting that their expression could be used as a blueprint for defining the cell of origin of different types of cancer and inform clinical decisions [70].

\section{Conclusions}

HOX genes are considered master regulators of cell fate determination during embryonic patterning. Positional and cell-specific HOX identities established during development are maintained during adulthood and enable tissue homeostasis. A specific HOX code is concealed in adult stem cells, which allows their self-renewal and differentiation potential. This code is then resolved during differentiation into different lineages, resulting in tissue-specific expression of HOX genes. In cancer, erasure of the HOX code causes a loss of cell identity and acquisition of a transformed phenotype and CSC characteristics (Figure 1). Current evidence supports a role of HOX genes in the function of normal and cancer stem cells, but the molecular mechanisms by which HOX gene deregulation alters stem cell function are still not fully known. Therefore, large scale genomic and proteomic approaches are needed to elucidate the function of HOX genes and their mode of action in regulating stem cells in normal and cancerous tissues. Given the critical role of HOX genes in lineage specification and acquisition of cell identity, HOX profiles could allow the development of new diagnostic and prognostic tools for personalized clinical management of cancer patients. In addition, they could be used to devise targeted therapies that could eliminate the so far elusive CSC. 


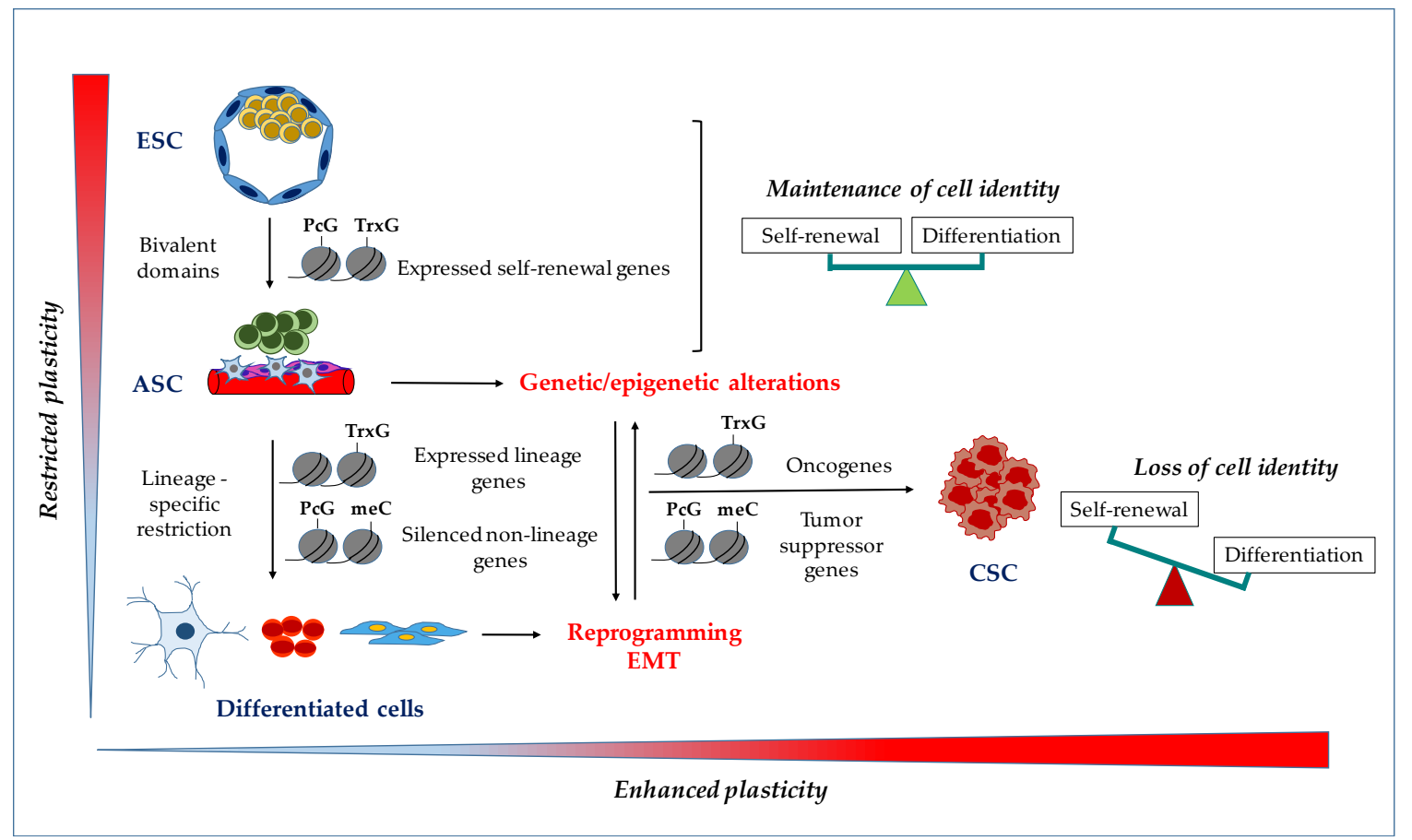

Figure 1. Role of HOX genes in the regulation of normal and cancer stem cells. HOX genes in ESC and ASC are epigenetically regulated by PcG and TrxG proteins. These epigenetic marks maintain stem cell identity and allow the expression of HOX genes in stem cells to regulate self-renewal and differential potential. After differentiation, lineage restriction is maintained by PcG proteins and DNA methylation. Genetic and epigenetic alterations induce reprogramming and EMT in either ASC or differentiated cells to induce their transformation into CSC. Re-expression of embryonic HOX genes and silencing of differentiation-specific genes drive CSC tumorigenicity and increase CSC plasticity. Abbreviations: ESC: embryonic stem cells; ASC: adult stem cells; PcG: Polycomb group of proteins; TrxG: Trithorax group of proteins; EMT: epithelial-to-mesenchymal transition; CSC: cancer stem cells.

Author Contributions: Conceptualization, C.A.; writing-C.A.; writing-review and editing, J.S., A.Z., C.A.; visualization, J.S., A.Z., C.A.; supervision, C.A.; funding acquisition, C.A.

Funding: This work was supported by the Biotechnology and Biological Sciences Research Council (grant BB/J014508/1 and BB/M008770/1).

Acknowledgments: We thank current and past lab members who contributed to HOX gene projects in our laboratory. We apologize to those authors whose work could not be cited due to space constraints.

Conflicts of Interest: The authors declare no conflict of interest. The funders had no role in the design of the study; in the collection, analyses, or interpretation of data; in the writing of the manuscript, or in the decision to publish the results.

\section{References}

1. Maconochie, M.; Nonchev, S.; Morrison, A.; Krumlauf, R. Paralogous Hox genes: Function and regulation. Annu. Rev. Genet. 1996, 30, 529-556. [CrossRef]

2. Duboule, D. The rise and fall of Hox gene clusters. Development 2007, 134, 2549-2560. [CrossRef]

3. Duboule, D.; Morata, G. Colinearity and functional hierarchy among genes of the homeotic complexes. Trends Genet. 1994, 10, 358-364. [CrossRef]

4. Young, T.; Deschamps, J. Hox, Cdx, and anteroposterior patterning in the mouse embryo. Curr. Top. Dev. Biol. 2009, 88, 235-255. [CrossRef] [PubMed]

5. Montavon, T.; Soshnikova, N. Hox gene regulation and timing in embryogenesis. Semin. Cell Dev. Biol. 2014, 34, 76-84. [CrossRef] [PubMed] 
6. Noordermeer, D.; Duboule, D. Chromatin architectures and Hox gene collinearity. Curr. Top. Dev. Biol. 2013, 104, 113-148. [CrossRef]

7. Bernstein, B.E.; Mikkelsen, T.S.; Xie, X.; Kamal, M.; Huebert, D.J.; Cuff, J.; Fry, B.; Meissner, A.; Wernig, M.; Plath, K.; et al. A bivalent chromatin structure marks key developmental genes in embryonic stem cells. Cell 2006, 125, 315-326. [CrossRef]

8. Samadieh, Y.; Favaedi, R.; Ramezanali, F.; Afsharian, P.; Aflatoonian, R.; Shahhoseini, M. Epigenetic dynamics of HOXA10 gene in infertile women with endometriosis. Reprod. Sci. 2019, 26, 88-96. [CrossRef]

9. Soshnikova, N.; Duboule, D. Epigenetic regulation of Hox gene activation: The waltz of methyls. Bioessays 2008, 30, 199-202. [CrossRef] [PubMed]

10. Rea, S.; Eisenhaber, F.; O'Carroll, D.; Strahl, B.D.; Sun, Z.-W.; Schmid, M.; Opravil, S.; Mechtler, K.; Ponting, C.P.; Allis, C.D. Regulation of chromatin structure by site-specific histone H3 methyltransferases. Nature 2000, 406, 593-599. [CrossRef] [PubMed]

11. Ehrlich, M.; Lacey, M. DNA methylation and differentiation: Silencing, upregulation and modulation of gene expression. Epigenomics 2013, 5, 553-568. [CrossRef]

12. Shah, M.; Allegrucci, C. Stem cell plasticity in development and cancer: Epigenetic origin of cancer stem cells. Subcell. Biochem. 2013, 61, 545-565. [CrossRef]

13. Ringrose, L.; Paro, R. Polycomb/Trithorax response elements and epigenetic memory of cell identity. Development 2007, 134, 223-232. [CrossRef] [PubMed]

14. Rinn, J.L.; Kertesz, M.; Wang, J.K.; Squazzo, S.L.; Xu, X.; Brugmann, S.A.; Goodnough, L.H.; Helms, J.A.; Farnham, P.J.; Segal, E.; et al. Functional demarcation of active and silent chromatin domains in human HOX loci by noncoding RNAs. Cell 2007, 129, 1311-1323. [CrossRef] [PubMed]

15. Sasaki, Y.T.; Sano, M.; Kin, T.; Asai, K.; Hirose, T. Coordinated expression of ncRNAs and HOX mRNAs in the human HOXA locus. Biochem. Biophys. Res. Commun. 2007, 357, 724-730. [CrossRef] [PubMed]

16. Hombria, J.C.; Lovegrove, B. Beyond homeosis-HOX function in morphogenesis and organogenesis. Differentiation 2003, 71, 461-476. [CrossRef] [PubMed]

17. Rezsohazy, R.; Saurin, A.J.; Maurel-Zaffran, C.; Graba, Y. Cellular and molecular insights into Hox protein action. Development 2015, 142, 1212-1227. [CrossRef] [PubMed]

18. Longobardi, E.; Penkov, D.; Mateos, D.; De Florian, G.; Torres, M.; Blasi, F. Biochemistry of the tale transcription factors PREP, MEIS, and PBX in vertebrates. Dev. Dyn. 2014, 243, 59-75. [CrossRef]

19. Dard, A.; Reboulet, J.; Jia, Y.; Bleicher, F.; Duffraisse, M.; Vanaker, J.M.; Forcet, C.; Merabet, S. Human HOX Proteins Use Diverse and Context-Dependent Motifs to Interact with TALE Class Cofactors. Cell Rep. 2018, 22, 3058-3071. [CrossRef]

20. Wang, K.C.; Helms, J.A.; Chang, H.Y. Regeneration, repair and remembering identity: The three Rs of Hox gene expression. Trends Cell Biol. 2009, 19, 268-275. [CrossRef]

21. Chang, H.Y.; Chi, J.T.; Dudoit, S.; Bondre, C.; van de Rijn, M.; Botstein, D.; Brown, P.O. Diversity, topographic differentiation, and positional memory in human fibroblasts. Proc. Natl. Acad. Sci. USA 2002, 99, 12877-12882. [CrossRef] [PubMed]

22. Rinn, J.L.; Bondre, C.; Gladstone, H.B.; Brown, P.O.; Chang, H.Y. Anatomic demarcation by positional variation in fibroblast gene expression programs. PLoS Genet. 2006, 2, e119. [CrossRef]

23. Donoghue, M.J.; Morris-Valero, R.; Johnson, Y.R.; Merlie, J.P.; Sanes, J.R. Mammalian muscle cells bear a cell-autonomous, heritable memory of their rostrocaudal position. Cell 1992, 69, 67-77. [CrossRef]

24. Grieshammer, U.; Sassoon, D.; Rosenthal, N. A transgene target for positional regulators marks early rostrocaudal specification of myogenic lineages. Cell 1992, 69, 79-93. [CrossRef]

25. Kamkar, F.; Xaymardan, M.; Asli, N.S. Hox-Mediated Spatial and Temporal Coding of Stem Cells in Homeostasis and Neoplasia. Stem Cells Dev. 2016, 25, 1282-1289. [CrossRef] [PubMed]

26. Deschamps, J.; Duboule, D. Embryonic timing, axial stem cells, chromatin dynamics, and the Hox clock. Genes Dev. 2017, 31, 1406-1416. [CrossRef] [PubMed]

27. Noordermeer, D.; Leleu, M.; Splinter, E.; Rougemont, J.; De Laat, W.; Duboule, D. The dynamic architecture of Hox gene clusters. Science (New York, N.Y.) 2011, 334, 222-225. [CrossRef]

28. Bahrami, S.B.; Veiseh, M.; Dunn, A.A.; Boudreau, N.J. Temporal changes in Hox gene expression accompany endothelial cell differentiation of embryonic stem cells. Cell Adhes. Migr. 2011, 5, 133-141. [CrossRef]

29. Riising, E.M.; Comet, I.; Leblanc, B.; Wu, X.; Johansen, J.V.; Helin, K. Gene silencing triggers polycomb repressive complex 2 recruitment to CpG islands genome wide. Mol. Cell 2014, 55, 347-360. [CrossRef] 
30. Di Croce, L.; Helin, K. Transcriptional regulation by Polycomb group proteins. Nat. Struct. Mol. Biol. 2013, 20, 1147-1155. [CrossRef]

31. Neijts, R.; Amin, S.; van Rooijen, C.; Deschamps, J. Cdx is crucial for the timing mechanism driving colinear Hox activation and defines a trunk segment in the Hox cluster topology. Dev. Biol. 2017, 422, 146-154. [CrossRef] [PubMed]

32. Neijts, R.; Amin, S.; van Rooijen, C.; Tan, S.; Creyghton, M.P.; de Laat, W.; Deschamps, J. Polarized regulatory landscape and Wnt responsiveness underlie Hox activation in embryos. Genes Dev. 2016, 30, 1937-1942. [CrossRef] [PubMed]

33. Kitajima, K.; Nakajima, M.; Kanokoda, M.; Kyba, M.; Dandapat, A.; Tolar, J.; Saito, M.K.; Toyoda, M.; Umezawa, A.; Hara, T. GSK3beta inhibition activates the CDX/HOX pathway and promotes hemogenic endothelial progenitor differentiation from human pluripotent stem cells. Exp. Hematol. 2016, 44, 68.e10-74.e10. [CrossRef] [PubMed]

34. Shahhoseini, M.; Taghizadeh, Z.; Hatami, M.; Baharvand, H. Retinoic acid dependent histone 3 demethylation of the clustered HOX genes during neural differentiation of human embryonic stem cells. Biochem. Cell Biol. 2013, 91, 116-122. [CrossRef] [PubMed]

35. Deschamps, J.; van Nes, J. Developmental regulation of the Hox genes during axial morphogenesis in the mouse. Development 2005, 132, 2931-2942. [CrossRef] [PubMed]

36. Langston, A.W.; Gudas, L.J. Retinoic acid and homeobox gene regulation. Curr. Opin. Genet. Dev. 1994, 4, 550-555. [CrossRef]

37. Kashyap, V.; Laursen, K.B.; Brenet, F.; Viale, A.J.; Scandura, J.M.; Gudas, L.J. RARgamma is essential for retinoic acid induced chromatin remodeling and transcriptional activation in embryonic stem cells. J. Cell Sci. 2013, 126, 999-1008. [CrossRef]

38. Kashyap, V.; Gudas, L.J.; Brenet, F.; Funk, P.; Viale, A.; Scandura, J.M. Epigenomic reorganization of the clustered Hox genes in embryonic stem cells induced by retinoic acid. J. Biol. Chem. 2011, 286, 3250-3260. [CrossRef] [PubMed]

39. Dhar, S.S.; Lee, S.H.; Chen, K.; Zhu, G.; Oh, W.; Allton, K.; Gafni, O.; Kim, Y.Z.; Tomoiga, A.S.; Barton, M.C.; et al. An essential role for UTX in resolution and activation of bivalent promoters. Nucleic Acids Res. 2016, 44, 3659-3674. [CrossRef] [PubMed]

40. Gouti, M.; Gavalas, A. Hoxb1 controls cell fate specification and proliferative capacity of neural stem and progenitor cells. Stem Cells 2008, 26, 1985-1997. [CrossRef]

41. Fan, R.; Bonde, S.; Gao, P.; Sotomayor, B.; Chen, C.; Mouw, T.; Zavazava, N.; Tan, K. Dynamic HoxB4-regulatory network during embryonic stem cell differentiation to hematopoietic cells. Blood 2012, 119, e139-e147. [CrossRef] [PubMed]

42. Lengerke, C.; Grauer, M.; Niebuhr, N.I.; Riedt, T.; Kanz, L.; Park, I.H.; Daley, G.Q. Hematopoietic development from human induced pluripotent stem cells. Ann. N. Y. Acad. Sci. 2009, 1176, 219-227. [CrossRef] [PubMed]

43. Bowles, K.M.; Vallier, L.; Smith, J.R.; Alexander, M.R.; Pedersen, R.A. HOXB4 overexpression promotes hematopoietic development by human embryonic stem cells. Stem Cells 2006, 24, 1359-1369. [CrossRef]

44. Larsen, B.M.; Marty-Santos, L.; Newman, M.; Lukacs, D.T.; Spence, J.R.; Wellik, D.M. Hox6 genes modulate in vitro differentiation of mESCs to insulin-producing cells. In Vitro Cell. Dev. Biol. Anim. 2016, 52, $974-982$. [CrossRef]

45. Sagi, B.; Maraghechi, P.; Urban, V.S.; Hegyi, B.; Szigeti, A.; Fajka-Boja, R.; Kudlik, G.; Nemet, K.; Monostori, E.; Gocza, E.; et al. Positional identity of murine mesenchymal stem cells resident in different organs is determined in the postsegmentation mesoderm. Stem Cells Dev. 2012, 21, 814-828. [CrossRef] [PubMed]

46. Ackema, K.B.; Charite, J. Mesenchymal stem cells from different organs are characterized by distinct topographic Hox codes. Stem Cells Dev. 2008, 17, 979-991. [CrossRef] [PubMed]

47. Liedtke, S.; Buchheiser, A.; Bosch, J.; Bosse, F.; Kruse, F.; Zhao, X.; Santourlidis, S.; Kogler, G. The HOX Code as a "biological fingerprint" to distinguish functionally distinct stem cell populations derived from cord blood. Stem Cell Res. 2010, 5, 40-50. [CrossRef] [PubMed]

48. Leucht, P.; Kim, J.B.; Amasha, R.; James, A.W.; Girod, S.; Helms, J.A. Embryonic origin and Hox status determine progenitor cell fate during adult bone regeneration. Development 2008, 135, 2845-2854. [CrossRef]

49. Alharbi, R.A.; Pettengell, R.; Pandha, H.S.; Morgan, R. The role of HOX genes in normal hematopoiesis and acute leukemia. Leukemia 2013, 27, 1000-1008. [CrossRef] 
50. Collins, E.M.; Thompson, A. HOX genes in normal, engineered and malignant hematopoiesis. Int. J. Dev. Biol. 2018, 62, 847-856. [CrossRef]

51. Hassan, M.Q.; Tare, R.; Lee, S.H.; Mandeville, M.; Weiner, B.; Montecino, M.; van Wijnen, A.J.; Stein, J.L.; Stein, G.S.; Lian, J.B. HOXA10 controls osteoblastogenesis by directly activating bone regulatory and phenotypic genes. Mol. Cell. Biol. 2007, 27, 3337-3352. [CrossRef]

52. Myers, C.; Charboneau, A.; Cheung, I.; Hanks, D.; Boudreau, N. Sustained expression of homeobox D10 inhibits angiogenesis. Am. J. Pathol. 2002, 161, 2099-2109. [CrossRef]

53. Seifert, A.; Werheid, D.F.; Knapp, S.M.; Tobiasch, E. Role of Hox genes in stem cell differentiation. World J. Stem Cells 2015, 7, 583-595. [CrossRef]

54. Briscoe, J.; Wilkinson, D.G. Establishing neuronal circuitry: Hox genes make the connection. Genes Dev. 2004, 18, 1643-1648. [CrossRef]

55. Shah, N.; Sukumar, S. The Hox genes and their roles in oncogenesis. Nat. Rev. Cancer 2010, 10, 361-371. [CrossRef]

56. Bhatlekar, S.; Fields, J.Z.; Boman, B.M. Role of HOX Genes in Stem Cell Differentiation and Cancer. Stem Cells Int. 2018, 2018, 3569493. [CrossRef]

57. Abate-Shen, C. Deregulated homeobox gene expression in cancer: Cause or consequence? Nat. Rev. Cancer 2002, 2, 777-785. [CrossRef]

58. Eoh, K.J.; Kim, H.J.; Lee, J.Y.; Nam, E.J.; Kim, S.; Kim, S.W.; Kim, Y.T. Upregulation of homeobox gene is correlated with poor survival outcomes in cervical cancer. Oncotarget 2017, 8, 84396-84402. [CrossRef]

59. Bhatlekar, S.; Fields, J.Z.; Boman, B.M. HOX genes and their role in the development of human cancers. J. Mol. Med. (Berl.) 2014, 92, 811-823. [CrossRef]

60. Ben Khadra, Y.; Said, K.; Thorndyke, M.; Martinez, P. Homeobox genes expressed during echinoderm arm regeneration. Biochem. Genet. 2014, 52, 166-180. [CrossRef]

61. Visvader, J.E.; Lindeman, G.J. Cancer stem cells in solid tumours: Accumulating evidence and unresolved questions. Nat. Rev. Cancer 2008, 8, 755-768. [CrossRef] [PubMed]

62. Gupta, P.B.; Pastushenko, I.; Skibinski, A.; Blanpain, C.; Kuperwasser, C. Phenotypic Plasticity: Driver of Cancer Initiation, Progression, and Therapy Resistance. Cell Stem Cell 2019, 24, 65-78. [CrossRef]

63. Campbell, L.L.; Polyak, K. Breast tumor heterogeneity: Cancer stem cells or clonal evolution? Cell Cycle 2007, 6, 2332-2338. [CrossRef]

64. Krivtsov, A.V.; Twomey, D.; Feng, Z.; Stubbs, M.C.; Wang, Y.; Faber, J.; Levine, J.E.; Wang, J.; Hahn, W.C.; Gilliland, D.G.; et al. Transformation from committed progenitor to leukaemia stem cell initiated by MLL-AF9. Nature 2006, 442, 818-822. [CrossRef] [PubMed]

65. Batlle, E.; Clevers, H. Cancer stem cells revisited. Nat. Med. 2017, 23, 1124-1134. [CrossRef]

66. Da Silva-Diz, V.; Lorenzo-Sanz, L.; Bernat-Peguera, A.; Lopez-Cerda, M.; Munoz, P. Cancer cell plasticity: Impact on tumor progression and therapy response. Semin. Cancer Biol. 2018, 53, 48-58. [CrossRef] [PubMed]

67. Meacham, C.E.; Morrison, S.J. Tumour heterogeneity and cancer cell plasticity. Nature 2013, 501, $328-337$. [CrossRef] [PubMed]

68. Wainwright, E.N.; Scaffidi, P. Epigenetics and Cancer Stem Cells: Unleashing, Hijacking, and Restricting Cellular Plasticity. Trends Cancer 2017, 3, 372-386. [CrossRef] [PubMed]

69. Rodrigues, M.F.; Esteves, C.M.; Xavier, F.C.; Nunes, F.D. Methylation status of homeobox genes in common human cancers. Genomics 2016, 108, 185-193. [CrossRef] [PubMed]

70. Shah, M.; Cardenas, R.; Wang, B.; Persson, J.; Mongan, N.P.; Grabowska, A.; Allegrucci, C. HOXC8 regulates self-renewal, differentiation and transformation of breast cancer stem cells. Mol. Cancer 2017, 16, 19. [CrossRef] [PubMed]

71. Tabuse, M.; Ohta, S.; Ohashi, Y.; Fukaya, R.; Misawa, A.; Yoshida, K.; Kawase, T.; Saya, H.; Thirant, C.; Chneiweiss, H.; et al. Functional analysis of HOXD9 in human gliomas and glioma cancer stem cells. Mol. Cancer 2011, 10, 60. [CrossRef] [PubMed]

72. Gallo, M.; Ho, J.; Coutinho, F.J.; Vanner, R.; Lee, L.; Head, R.; Ling, E.K.; Clarke, I.D.; Dirks, P.B. A tumorigenic MLL-homeobox network in human glioblastoma stem cells. Cancer Res. 2013, 73, 417-427. [CrossRef] [PubMed]

73. Qian, P.; De Kumar, B.; He, X.C.; Nolte, C.; Gogol, M.; Ahn, Y.; Chen, S.; Li, Z.; Xu, H.; Perry, J.M.; et al. Retinoid-Sensitive Epigenetic Regulation of the Hoxb Cluster Maintains Normal Hematopoiesis and Inhibits Leukemogenesis. Cell Stem Cell 2018, 22, 740.e7-754.e7. [CrossRef] [PubMed] 
74. Castro-Oropeza, R.; Melendez-Zajgla, J.; Maldonado, V.; Vazquez-Santillan, K. The emerging role of lncRNAs in the regulation of cancer stem cells. Cell. Oncol. (Dordr.) 2018, 41, 585-603. [CrossRef] [PubMed]

75. Padua Alves, C.; Fonseca, A.S.; Muys, B.R.; de Barros, E.L.B.R.; Burger, M.C.; de Souza, J.E.; Valente, V.; Zago, M.A.; Silva, W.A., Jr. Brief report: The lincRNA Hotair is required for epithelial-to-mesenchymal transition and stemness maintenance of cancer cell lines. Stem Cells 2013, 31, 2827-2832. [CrossRef] [PubMed]

76. Zhang, H.; Cai, K.; Wang, J.; Wang, X.; Cheng, K.; Shi, F.; Jiang, L.; Zhang, Y.; Dou, J. MiR-7, inhibited indirectly by lincRNA HOTAIR, directly inhibits SETDB1 and reverses the EMT of breast cancer stem cells by downregulating the STAT3 pathway. Stem Cells 2014, 32, 2858-2868. [CrossRef] [PubMed]

77. Li, H.; An, J.; Wu, M.; Zheng, Q.; Gui, X.; Li, T.; Pu, H.; Lu, D. LncRNA HOTAIR promotes human liver cancer stem cell malignant growth through downregulation of SETD2. Oncotarget 2015, 6, 27847-27864. [CrossRef] [PubMed]

78. Liu, Y.; Luo, F.; Xu, Y.; Wang, B.; Zhao, Y.; Xu, W.; Shi, L.; Lu, X.; Liu, Q. Epithelial-mesenchymal transition and cancer stem cells, mediated by a long non-coding RNA, HOTAIR, are involved in cell malignant transformation induced by cigarette smoke extract. Toxicol. Appl. Pharmacol. 2015, 282, 9-19. [CrossRef]

79. Fang, K.; Liu, P.; Dong, S.; Guo, Y.; Cui, X.; Zhu, X.; Li, X.; Jiang, L.; Liu, T.; Wu, Y. Magnetofection based on superparamagnetic iron oxide nanoparticle-mediated low lncRNA HOTAIR expression decreases the proliferation and invasion of glioma stem cells. Int. J. Oncol. 2016, 49, 509-518. [CrossRef]

80. Fu, Z.; Chen, C.; Zhou, Q.; Wang, Y.; Zhao, Y.; Zhao, X.; Li, W.; Zheng, S.; Ye, H.; Wang, L.; et al. LncRNA HOTTIP modulates cancer stem cell properties in human pancreatic cancer by regulating HOXA9. Cancer Lett. 2017, 410, 68-81. [CrossRef]

81. Bhatlekar, S.; Ertel, A.; Gonye, G.E.; Fields, J.Z.; Boman, B.M. Gene expression signatures for HOXA4, HOXA9, and HOXD10 reveal alterations in transcriptional regulatory networks in colon cancer. J. Cell. Physiol. 2018. [CrossRef] [PubMed]

82. Takeda, A.; Goolsby, C.; Yaseen, N.R. NUP98-HOXA9 induces long-term proliferation and blocks differentiation of primary human CD34+ hematopoietic cells. Cancer Res. 2006, 66, 6628-6637. [CrossRef] [PubMed]

83. Velu, C.S.; Chaubey, A.; Phelan, J.D.; Horman, S.R.; Wunderlich, M.; Guzman, M.L.; Jegga, A.G.; Zeleznik-Le, N.J.; Chen, J.; Mulloy, J.C.; et al. Therapeutic antagonists of microRNAs deplete leukemia-initiating cell activity. J. Clin. Investig. 2014, 124, 222-236. [CrossRef] [PubMed]

84. Fu, H.; Fu, L.; Xie, C.; Zuo, W.S.; Liu, Y.S.; Zheng, M.Z.; Yu, J.M. miR-375 inhibits cancer stem cell phenotype and tamoxifen resistance by degrading HOXB3 in human ER-positive breast cancer. Oncol. Rep. 2017, 37, 1093-1099. [CrossRef] [PubMed]

85. Teo, W.W.; Merino, V.F.; Cho, S.; Korangath, P.; Liang, X.; Wu, R.C.; Neumann, N.M.; Ewald, A.J.; Sukumar, S. HOXA5 determines cell fate transition and impedes tumor initiation and progression in breast cancer through regulation of E-cadherin and CD24. Oncogene 2016, 35, 5539-5551. [CrossRef]

86. Ordonez-Moran, P.; Dafflon, C.; Imajo, M.; Nishida, E.; Huelsken, J. HOXA5 Counteracts Stem Cell Traits by Inhibiting Wnt Signaling in Colorectal Cancer. Cancer Cell 2015, 28, 815-829. [CrossRef]

87. Bhatlekar, S.; Viswanathan, V.; Fields, J.Z.; Boman, B.M. Overexpression of HOXA4 and HOXA9 genes promotes self-renewal and contributes to colon cancer stem cell overpopulation. J. Cell. Physiol. 2018, 233, 727-735. [CrossRef]

88. Haria, D.; Naora, H. Homeobox Gene Deregulation: Impact on the Hallmarks of Cancer. Cancer Hallm. 2013, 1,67-76. [CrossRef]

89. Wu, X.; Chen, H.; Parker, B.; Rubin, E.; Zhu, T.; Lee, J.S.; Argani, P.; Sukumar, S. HOXB7, a homeodomain protein, is overexpressed in breast cancer and confers epithelial-mesenchymal transition. Cancer Res. 2006, 66, 9527-9534. [CrossRef]

90. Cai, J.Q.; Xu, X.W.; Mou, Y.P.; Chen, K.; Pan, Y.; Wu, D. Upregulation of HOXB7 promotes the tumorigenesis and progression of gastric cancer and correlates with clinical characteristics. Tumour Biol. 2016, 37, 1641-1650. [CrossRef]

91. Liao, W.T.; Jiang, D.; Yuan, J.; Cui, Y.M.; Shi, X.W.; Chen, C.M.; Bian, X.W.; Deng, Y.J.; Ding, Y.Q. HOXB7 as a prognostic factor and mediator of colorectal cancer progression. Clin. Cancer Res. 2011, 17, 3569-3578. [CrossRef] [PubMed] 
92. Topisirovic, I.; Kentsis, A.; Perez, J.M.; Guzman, M.L.; Jordan, C.T.; Borden, K.L. Eukaryotic translation initiation factor 4E activity is modulated by HOXA9 at multiple levels. Mol. Cell. Biol. 2005, 25, 1100-1112. [CrossRef]

93. Rubin, E.; Wu, X.; Zhu, T.; Cheung, J.C.; Chen, H.; Lorincz, A.; Pandita, R.K.; Sharma, G.G.; Ha, H.C.; Gasson, J.; et al. A role for the HOXB7 homeodomain protein in DNA repair. Cancer Res. 2007, 67, 1527-1535. [CrossRef] [PubMed]

94. Jin, K.; Kong, X.; Shah, T.; Penet, M.F.; Wildes, F.; Sgroi, D.C.; Ma, X.J.; Huang, Y.; Kallioniemi, A.; Landberg, G.; et al. The HOXB7 protein renders breast cancer cells resistant to tamoxifen through activation of the EGFR pathway. Proc. Natl. Acad. Sci. USA 2012, 109, 2736-2741. [CrossRef]

95. Raman, V.; Martensen, S.A.; Reisman, D.; Evron, E.; Odenwald, W.F.; Jaffee, E.; Marks, J.; Sukumar, S. Compromised HOXA5 function can limit p53 expression in human breast tumours. Nature 2000, 405, 974-978. [CrossRef] [PubMed]

96. Yang, Q.S.; Li, B.; Xu, G.; Yang, S.Q.; Wang, P.; Tang, H.H.; Liu, Y.Y. Long noncoding RNA LINC00483/microRNA-144 regulates radiosensitivity and epithelial-mesenchymal transition in lung adenocarcinoma by interacting with HOXA10. J. Cell. Physiol. 2019. [CrossRef]

97. Yoshida, H.; Broaddus, R.; Cheng, W.; Xie, S.; Naora, H. Deregulation of the HOXA10 homeobox gene in endometrial carcinoma: Role in epithelial-mesenchymal transition. Cancer Res. 2006, 66, 889-897. [CrossRef]

98. Dang, C.V.; Reddy, E.P.; Shokat, K.M.; Soucek, L. Drugging the 'undruggable' cancer targets. Nat. Rev. Cancer 2017, 17, 502-508. [CrossRef]

99. Lappin, T.R.; Grier, D.G.; Thompson, A.; Halliday, H.L. HOX genes: Seductive science, mysterious mechanisms. Ulster Med. J. 2006, 75, 23-31. [PubMed]

100. Luo, Z.; Rhie, S.K.; Farnham, P.J. The Enigmatic HOX Genes: Can We Crack Their Code? Cancers 2019, 11, 323. [CrossRef]

101. Morgan, R.; El-Tanani, M.; Hunter, K.D.; Harrington, K.J.; Pandha, H.S. Targeting HOX/PBX dimers in cancer. Oncotarget 2017, 8, 32322-32331. [CrossRef] [PubMed]

102. Northcott, J.M.; Northey, J.J.; Barnes, J.M.; Weaver, V.M. Fighting the force: Potential of homeobox genes for tumor microenvironment regulation. Biochim. Biophys. Acta 2015, 1855, 248-253. [CrossRef] [PubMed]

103. Rhoads, K.; Arderiu, G.; Charboneau, A.; Hansen, S.L.; Hoffman, W.; Boudreau, N. A role for Hox A5 in regulating angiogenesis and vascular patterning. Lymphat. Res. Biol. 2005, 3, 240-252. [CrossRef] [PubMed]

104. Carrio, M.; Arderiu, G.; Myers, C.; Boudreau, N.J. Homeobox D10 induces phenotypic reversion of breast tumor cells in a three-dimensional culture model. Cancer Res. 2005, 65, 7177-7185. [CrossRef]

105. Harris, W.J.; Huang, X.; Lynch, J.T.; Spencer, G.J.; Hitchin, J.R.; Li, Y.; Ciceri, F.; Blaser, J.G.; Greystoke, B.F.; Jordan, A.M.; et al. The histone demethylase KDM1A sustains the oncogenic potential of MLL-AF9 leukemia stem cells. Cancer Cell 2012, 21, 473-487. [CrossRef] [PubMed]

106. Nowak, D.; Stewart, D.; Koeffler, H.P. Differentiation therapy of leukemia: 3 decades of development. Blood 2009, 113, 3655-3665. [CrossRef] [PubMed]

107. Morgan, R.; El-Tanani, M. HOX Genes as Potential Markers of Circulating Tumour Cells. Curr. Mol. Med. 2016, 16, 322-327. [CrossRef]

(C) 2019 by the authors. Licensee MDPI, Basel, Switzerland. This article is an open access article distributed under the terms and conditions of the Creative Commons Attribution (CC BY) license (http://creativecommons.org/licenses/by/4.0/). 